Sains Malaysiana 50(2)(2021): 409-418

http://dx.doi.org/10.17576/jsm-2021-5002-12

\title{
Penghasilan Asid Laktik D daripada Hidrolisat Sabut Kelapa Tua dan Muda
}

(Production of D Lactic Acid from Hydrolysate Brown and Green Coconut Husk)

\author{
Nur Nadhirah Muhamad Nor, Teo Pui Leng, Nur Akmal Solehah Din \& Nurul Aqilah Mohd Zaini*
}

\begin{abstract}
ABSTRAK
Penghasilan asid laktik D semakin mendapat perhatian kerana sifat polimernya, poli asid laktik D, yang termostabil. Kajian ini dijalankan untuk menghasilkan asid laktik D daripada sisa pertanian yang tidak bernilai tinggi seperti sabut kelapa tua (SKT) dan sabut kelapa muda (SKM) melalui teknologi fermentasi. Peringkat pertama kajian, SKT dan SKM dikenakan pra-rawatan beralkali menggunakan 5\% larutan natrium hidroksida pada suhu $121{ }^{\circ} \mathrm{C}$ selama 15 minit untuk menyingkirkan komponen lignin dan hemiselulosa. Kemudian, dua kaedah hidrolisis dikaji, iaitu hidrolisis berenzim dengan menggunakan enzim Acellerase 1500 (1, 5 dan 10\%, i/i) dan hidrolisis berasid dengan menggunakan asid sulfurik (1, 3 dan 5\%, i/i). Keputusan menunjukkan hidrolisis berenzim dengan kepekatan 10\% enzim Accellerase 1500 (11.09 mg/mL) lebih cekap menukarkan selulosa kepada gula penurun berbanding hidrolisis berasid (0.87 mg) $\mathrm{mL}$ ) dalam hidrolisat SKT. Manakala, bagi hidrolisat SKM, 5\% enzim Accellerase menghasilkan kepekatan gula penurun yang lebih tinggi berbanding hidrolisis berasid dengan 15.00 dan $1.02 \mathrm{mg} / \mathrm{mL}$. Kadar penukaran gula penurun yang maksimum didapati daripada hidrolisis berenzim SKT dan SKM dengan 55\% dan 60\%. Pada peringkat kedua, hidrolisat yang mengandungi gula penurun yang tinggi digunakan sebagai sumber karbon untuk penghasilan asid laktik D oleh Lactobacillus coryniformis subsp. torquen melalui proses fermentasi ( 48 jam, $37^{\circ} \mathrm{C}, 150 \mathrm{rpm}$ ). Pada akhir proses fermentasi, sebanyak $4.93 \mathrm{~g} / \mathrm{L}$ penghasilan asid laktik D direkodkan dalam kaldu hidrolisat SKT dan $3.98 \mathrm{~g} / \mathrm{L}$ asid laktik D terhasil dalam kaldu hidrolisat SKM dengan pH kaldu fermentasi tidak dikawal. Kesimpulannya, selulosa dalam kedua-dua sampel SKT dan SKM boleh diuraikan kepada gula penurun melalui hidrolisis berenzim dan seterusnya berpotensi untuk digunakan sebagai substrat bagi menghasilkan asid laktik D melalui proses fermentasi.
\end{abstract}

Kata kunci: Asid laktik D; biojisim sabut kelapa; hidrolisis berenzim; hidrolisis berasid; proses fermentasi

\section{ABSTRACT}

Production of D lactic acid is gaining attention due to thermostable properties of its polymer, Poly-D-lactic acid. This study was conducted to produce D lactic acid from low-value agricultural waste such as brown coconut husk (SKT) and green coconut husk (SKM) through fermentation technology. In the first phase of the study, SKT and SKM were pre-treated with alkaline solution using 5\% sodium hydroxide solution at $121^{\circ} \mathrm{C}$ for 15 min to remove lignin and hemicellulose components. Then, two hydrolysis methods were studied, namely enzymatic hydrolysis using Acellerase $1500(1,5$ and $10 \%, v / v)$ and acidic hydrolysis using sulfuric acid $(1,3$ and 5\%,v/v). The results showed that 10\% Accellerase $1500(11.09 \mathrm{mg} / \mathrm{mL})$ was more efficient in converting cellulose to reduced sugar than acidic hydrolysis $(0.87 \mathrm{mg} / \mathrm{mL})$ in SKT hydrolysis. Meanwhile, for SKM hydrolysis, 5\% Accellerase enzyme yielded a higher sugar concentration than acidic hydrolysis with 15.00 and $1.02 \mathrm{mg} / \mathrm{mL}$, respectively. The highest conversion rates of sugar were obtained from the hydrolysis of SKT and SKM by 55\% and 60\%, respectively. In the second stage of this research, hydrolysate of high reducing sugars was used as a carbon source for the production of D lactic acid by Lactobacillus coryniformis subsp. torquen through the fermentation $\left(48 \mathrm{~h}, 37^{\circ} \mathrm{C}, 150 \mathrm{rpm}\right)$. At the end of the fermentation process, $4.93 \mathrm{~g} / \mathrm{L}$ of lactic acid production was recorded in SKT hydrolysate and $3.98 \mathrm{~g} / \mathrm{L}$ lactic acid was produced in SKM hydrolysate, where the $\mathrm{pH}$ of the fermentation broth was not controlled. In conclusion, cellulose in both SKT and SKM samples can be hydrolysed into reducing sugars through enzymatic hydrolysis and subsequently shows potential to be used as a substrate for D lactic acid production through fermentation.

Keywords: Acidic hydrolysis; coconut husk biomass; D lactic acid; enzymatic hydrolysis; fermentation

\section{PENDAHULUAN}

Kelapa merupakan tanaman ke-empat terpenting di Malaysia selepas kelapa sawit, getah dan padi dengan keluasan sebanyak 81,585 hektar pada tahun 2018. Pada masa yang sama, sisa biojisim sabut kelapa sama ada sabut kelapa tua (SKT) mahupun sabut kelapa muda (SKM) kini 
semakin bertambah kerana kepelbagaian penggunaan buah kelapa dalam pelbagai sektor terutamanya industri makanan. Pada masa kini, kira-kira 504700 tan metrik setahun buah kelapa dikeluarkan oleh Malaysia (Ysuhaimi 2018). Biojisim sabut kelapa memiliki komposisi yang paling tinggi dalam buah kelapa iaitu sebanyak 35\%. Oleh itu, jika bahan buangan ini dibuang kepada alam sekitar tanpa perlakuan yang sesuai, bahan buangan tersebut boleh menyebabkan masalah alam sekitar yang serius (Sommer et al. 2016). Walau bagaimanapun, biojisim sabut kelapa ini sebenarnya kaya dengan sebatian lignoselulosa yang terdiri daripada selulosa, hemiselulosa dan lignin. Sebatian ini membentuk sebanyak $90 \%$ berat kering biojisim (Lin \& Tanaka 2006). Secara teorinya, kandungan selulosa yang hadir dalam SKT dan SKM boleh diuraikan kepada glukosa yang mampu menjadi sumber karbon semasa proses fermentasi bagi penghasilan produk yang lebih bernilai tinggi seperti asid laktik (Abdel-Rahman et al. 2010).

Manakala asid laktik (asid 2-hidroksipropanoik, $\mathrm{CH}_{3}-$ $\mathrm{CH}(\mathrm{OH})-\mathrm{COOH})$ adalah asid organik semula jadi dengan sejarah penggunaan yang luas dalam industri makanan dan bukan makanan, termasuk industri kosmetik, tekstil dan farmaseutikal. Pada masa kini, terdapat peningkatan pengeluaran asid laktik terutamanya asid laktik D kerana dapat menghasilkan polimer asid laktik D (PDLA) yang bersifat termostabil, mudah terbiodegradasi, bioserasi dan mesra alam (Mohd Zaini et al. 2019). Walau bagaimanapun, kos penggunaan bahan mentah seperti kanji dan gula terproses yang tinggi telah menjadi cabaran dalam penghasilan asid laktik. Oleh itu, penggunaan bahan mentah yang murah adalah penting dalam pengeluaran asid laktik kerana kebiasaannya pengeluar polimer dan pengguna industri lain memerlukan asid laktik dalam kuantiti yang banyak dengan harga yang rendah. Justeru, asid laktik telah mula dihasilkan melalui proses fermentasi daripada hidrolisat bahan buangan pertanian yang kaya dengan sumber karbon. Sebanyak $90 \%$ asid laktik dihasilkan melalui proses fermentasi kerana mempunyai banyak kelebihan berbanding sintesis secara kimia (Dumbrepatil et al. 2008).

Walau bagaimanapun, selulosa dan hemiselulosa dalam sebatian lignoselulosa daripada sisa buangan pertanian tidak boleh digunakan secara terus semasa proses fermentasi kerana terdapat ikatan yang kuat wujud daripada lignin yang menghalang aktiviti enzim berlaku dengan cekap (Abdel-Rahman et al. 2010; Mohamed et al. 2013). Komponen lignoselulosa boleh diuraikan kepada gula ringkas yang sesuai dijadikan sumber karbon melalui pelbagai kaedah hidrolisis seperti hidrolisis berasid, hidrolisis beralkali atau hidrolisis berenzim (Kucharska et al. 2018). Seterusnya, gula ringkas, terutamanya glukosa yang terhasil daripada molekul selulosa boleh digunakan sebagai substrat semasa proses fermentasi.
Justeru, kajian ini dijalankan untuk mengkaji potensi SKT dan SKM sebagai bahan suapan fermentasi untuk menghasilkan asid laktik D. Kesan pra-rawatan beralkali ke atas penguraian selulosa SKT dan SKM melalui kaedah hidrolisis berenzim dan hidrolisis berasid turut dikaji. Seterusnya, kondisi terbaik yang dapat menguraikan selulosa SKT dan SKM kepada gula ringkas pada kepekatan yang tinggi digunakan untuk menghasilkan hidrolisat bagi menghasilkan asid laktik D melalui proses fermentasi.

\section{BAHAN DAN KAEDAH}

\section{BAHAN MENTAH DAN BAHAN KIMIA}

Sampel SKT dibekalkan oleh peniaga kelapa berlesen dari kilang pemprosesan kelapa di Ampang, Selangor. Manakala, sampel SKM diperoleh daripada penjual air kelapa muda di Seksyen 3, Bandar Baru Bangi, Selangor. Bahan-bahan kimia yang digunakan adalah asid sulfurik $\left(\mathrm{H}_{2} \mathrm{SO}_{4}\right)$, natrium hidroksida $(\mathrm{NaOH})$, kaldu De Man, Rogosa and Sharpe (MRS) (Thermo Scientific ${ }^{\text {TM}}$ ), ekstrak yis, enzim Accellerase 1500, natrium hidroksida, asid 3,5- dinitrosalicyclic, natrium kalium tartrat tetrahidrat, reagen asetik/nitrik, setil trimetilamonium bromida, larutan Bradford, natrium klorida $(\mathrm{NaCl})$, larutan ferum (III) klorida, glukosa dan bovine serum albumin (BSA). Bakteria Lactobacillus coryniformis subsp. torquens (DSM20004) diperoleh dari Collection of Microorganisms and Cell Cultures (DSMZ), German.

\section{PENYEDIAAN SAMPEL SABUT KELAPA}

SKT dan SKM dikeringkan pada suhu $50{ }^{\circ} \mathrm{C}$ selama 2 hari dalam ketuhar (Memmert Incubator Oven INB200) sehingga berat malar diperoleh dan seterusnya dikisarkan menggunakan pengisar (Waring 7010HG blender). Kemudian, serbuk sabut kelapa ditapis $(0.841 \mathrm{~mm})$ untuk mendapatkan saiz yang sama. Selepas itu, sabut kelapa disimpan di dalam bekas kedap udara pada suhu $25^{\circ} \mathrm{C}$.

\section{PRA-RAWATAN BERALKALI}

Proses pra-rawatan dijalankan secara kimia dengan menggunakan natrium hidroksida $(\mathrm{NaOH})$ mengikut Zaini et al. (2019) dengan sedikit pengubahsuaian. Sebanyak $100 \mathrm{~g}$ sampel ditimbang dan dimasukkan ke dalam botol Schott. Kemudian, $1000 \mathrm{~mL}$ 5\% (NaOH ditambah ke dalam sampel dan diautoklaf pada suhu $121^{\circ} \mathrm{C}(\sim 16 \mathrm{psi})$ selama 30 minit. Setelah sejuk, SKM dan SKT diemparkan pada 10000 rpm selama 10 minit. Pelet SKM dan SKT yang telah dikenakan pra-rawatan diasingkan dan dikumpulkan. Kemudian, pelet tersebut dibasuh dengan air suling dan dineutralkan dengan $6 \mathrm{M}$ larutan asid hidroklorik $(\mathrm{HCl})$ 
sehingga $\mathrm{pH}$ 6-7. Seterusnya, pelet dikeringkan di dalam ketuhar (Memmert Incubator Oven INB200) pada suhu $70-80{ }^{\circ} \mathrm{C}$ selama 24 jam. Uji kaji ini dijalankan sebanyak dua replikasi.

\section{ANALISIS MORFOLOGI PERMUKAAN SKT DAN SKM}

Kesan pra-rawatan beralkali pada ciri morfologi permukaan SKT dan SKM dikaji berdasarkan kaedah Yang (2006) dengan alat pengimbasan Mikroskop Elektron (VP-SEM LEO 1450VP), United Kingdom. Sampel disaluti dengan emas sebelum pencerapan dilakukan. Filamen dihidupkan dan nilai voltan ditetapkan pada $20 \mathrm{kV}$.

\section{HIDROLISIS BERASID SABUT KELAPA}

Sebanyak $2.5 \mathrm{~g}$ sampel ditimbang dan dimasukkan ke dalam botol Scott. Sebanyak $50 \mathrm{~mL}$ larutan asid sulfurik yang berbeza kepekatan (1, 3 dan 5\%, i/i) ditambahkan ke dalam botol Scott. Setiap campuran ini diautoklaf pada $121{ }^{\circ} \mathrm{C}$ selama 30 minit. Selepas itu, sampel dibiarkan sejuk pada suhu bilik dan kemudiannya diemparkan pada $11,200 \times$ g selama 15 minit pada suhu bilik. Supernatan dan pelet yang terhasil kemudiannya dikumpulkan. Langkah ini diulang bagi $1 \mathrm{~g}$ sampel pra-rawatan. Gula penurun ditentukan dengan menggunakan kaedah DNS. Uji kaji ini dijalankan sebanyak dua replikasi dan merujuk kepada Mansuit et al. (2015) dengan sedikit pengubahsuaian.

\section{HIDROLISIS BERENZIM SABUT KELAPA}

Kaedah hidrolisis berenzim adalah merujuk kepada Zaini et al. (2019) dengan sedikit pengubahsuaian. Sebanyak $0.5 \mathrm{~g}$ sampel tanpa rawatan ditimbang dan dimasukkan ke dalam botol universal. Sebanyak $10 \mathrm{~mL}$ larutan enzim Accellerase 1500 yang berbeza kepekatan (1, 5 dan $10 \%, \mathrm{i} / \mathrm{i})$ ditambahkan ke dalam botol universal. Setiap campuran ini dibiarkan pada penggoncang berpusing pada kelajuan $300 \mathrm{rpm}$ pada suhu $50^{\circ} \mathrm{C}$ selama 24 jam. Sampel kemudiannya dimasukkan ke dalam kukusan air pada suhu $80-95{ }^{\circ} \mathrm{C}$ selama 10 minit untuk penyahaktifan enzim. Seterusnya, setiap sampel diemparkan pada 10 $000 \mathrm{rpm}$ selama 15 minit pada suhu bilik. Supernatan dan pelet yang terhasil kemudiannya dikumpulkan. Gula penurun ditentukan dengan menggunakan kaedah DNS. Uji kaji ini dijalankan sebanyak dua replikasi. Langkah ini diulang dengan $0.2 \mathrm{~g}$ sampel pra-rawatan.

\section{PENGHASILAN ASID LAKTIK D MELALUI PROSES FERMENTASI \\ PENYEDIAAN MEDIA INOKULUM}

Stok gliserol kultur Lactobacillus coryniformis subsp. torquens (DSM20004 ${ }^{\mathrm{T}}$ ) yang disimpan pada -20
${ }^{\circ} \mathrm{C}$ dimasukkan ke dalam $50 \mathrm{~mL}$ larutan kaldu MRS selama 18 jam pada suhu $37^{\circ} \mathrm{C}$ (Mohd Zaini et al. 2019).

\section{PENGHASILAN ASID LAKTIK D DARIPADA HIDROLISAT SABUT KELAPA}

Sebanyak $45 \mathrm{~mL}$ hidrolisat yang dihasilkan selepas proses hidrolisis berenzim dimasukkan ke dalam kelalang kon yang ditutup dengan kapas dan 1 g ekstrak yis (Oxoid ${ }^{\mathrm{TM}}$ ) ditambah ke dalam kelalang kon tersebut untuk diautoklaf pada $121{ }^{\circ} \mathrm{C}$ selama 15 minit. Kemudian, sebanyak 5 $\mathrm{mL}$ inokulum bakteria $L$. coryniformis subsp. torquens ditambah ke dalam kelalang kon $(10 \%$, i/i). Setiap sampel diletakkan ke dalam penggoncang berpusing (IKA incubator shaker KS 3000 i control) dan proses fermentasi dijalankan selama 48 jam pada suhu $37^{\circ} \mathrm{C}$. Persampelan diambil pada 0 jam diikuti dengan $6,12,24,30,36$ dan 48 jam. Langkah ini dijalankan sebanyak dua replikasi. Kaedah ini merujuk kepada Mohd Zaini et al. (2019) dengan sedikit pengubahsuaian.

\section{PARAMETER ANALISIS}

PENENTUAN KANDUNGAN GULA PENURUN (DNS) Penentuan gula penurun ditentukan dengan menggunakan kaedah DNS merujuk kepada Garriga et al. (2017) dengan sedikit pengubahsuaian. Sebanyak $100 \mathrm{~mL}$ larutan reaktif DNS disediakan dengan mencampurkan larutan A (1 g DNS ke dalam $20 \mathrm{~mL} 2 \mathrm{M} \mathrm{NaOH}$ ) dan larutan B (30 g natrium dan kalium tartrat tetrahidrat ke dalam $50 \mathrm{~mL}$ air sulingan). Larutan tersebut disimpan pada suhu $4{ }^{\circ} \mathrm{C} .100$ $\mu \mathrm{L}$ hidrolisat sampel ditambah dengan $1 \mu \mathrm{L}$ larutan DNS di dalam tiub. Tiub diletakkan di dalam kukusan air pada suhu $100{ }^{\circ} \mathrm{C}$ selama 5 minit dan kemudian disejukkan pada suhu bilik. Isi padu sampel dilarutkan dengan $1 \mathrm{~mL}$ air suling. Sampel dianalisis pada gelombang $540 \mathrm{~nm}$ dalam spektrofotometer. Bacaannya dibandingkan dengan larutan kosong dan sampel digantikan dengan air suling.

\section{PENENTUAN KANDUNGAN ASID LAKTIK}

Kandungan asid laktik pula ditentukan dengan merujuk kepada kaedah Borshchevskaya et al. (2016). Sebanyak $50 \mu \mathrm{L}$ sampel fermentasi yang mengandungi asid laktik ditambah ke dalam $2 \mathrm{~mL} \mathrm{0.2 \%} \mathrm{larutan} \mathrm{FeCl}_{3}$. Seterusnya, kedua-dua larutan tersebut dikacau dan serapan diukur pada $390 \mathrm{~nm}$ bersama dengan larutan rujukan $(2 \mathrm{~mL} \mathrm{0.2 \%}$ larutan $\mathrm{FeCl}_{3}$ ). Tindak balas kimia dan ukuran tersebut dijalankan pada suhu $25+5{ }^{\circ} \mathrm{C}$. Warna larutan tersebut akan stabil selama 15 minit.

\section{ANALISIS STATISTIK}

Semua data yang diperoleh dianalisis dengan kaedah analisis one-way ANOVA dengan menggunakan perisian 
Minitab versi 17. Ujian Tukey's digunakan untuk menentukan perbezaan signifikan bagi nilai min pada aras keyakinan $95 \%(\mathrm{p}<0.05)$.

\section{HASIL DAN PERBINCANGAN}

\section{KESAN PRA-RAWATAN KE ATAS MORFOLOGI SKT DAN} SKM

Permukaan SKM dan SKT tanpa pra-rawatan dan yang dikenakan pra-rawatan beralkali $\left(5 \% \mathrm{NaOH}, 121^{\circ} \mathrm{C}, 30\right.$ min) telah diperhatikan dengan menggunakan VSEM untuk membandingkan perubahan struktur morfologi yang mungkin berlaku (Rajah 1). Tanpa pra rawatan, permukaan SKT diperhatikan lebih licin, padat dan sekata seperti yang dilaporkan dalam kajian Yew at al. (2019) jika dibandingkan dengan permukaan sampel SKM. Ini adalah kerana secara semula jadi, SKT mengandungi kandungan lignin yang lebih tinggi berbanding SKM (Lomelí-Ramírez et al. 2018). Selepas proses prarawatan beralkali $(\mathrm{NaOH})$, permukaan SKM dan SKT kelihatan terbuka. Ikatan selulosa yang renggang di antara serat juga dapat terlihat jelas pada permukaan SKM dan SKT selepas pra-rawatan beralkali. Perbezaan struktur permukaan ini menjelaskan bahawa penambahan $\mathrm{NaOH}$ dapat memisahkan ikatan pada dinding sel lignoselulosa dan menyebabkan struktur dalaman serat kelapa mudah terdedah kepada proses hidrolisis (Ciftci et al. 2015). Menurut Bensah dan Mensah (2013), pra-rawatan mampu mengubah suai struktur biojisim lignoselulosa dengan menyingkirkan komponen lignin dan karbohidrat (hemiselulosa) yang seterusnya mengurangkan darjah pempolimeran dan pengkristalan selulosa. Tambahan pula, Ringkas (2016) telah melaporkan bahawa rawatan beralkali boleh menyebabkan gangguan pada struktur gentian dengan memusnahkan dinding sel, menghidrolisis lignin atau hemiselulosa dan mewujudkan beberapa liang besar. Maka, lebih banyak selulosa terdedah kepada enzim dan akhirnya menyebabkan peningkatan kadar penghasilan glukosa.

\section{HIDROLISIS BERASID}

Proses memutuskan ikatan glikosidik antara molekul selulosa untuk membentuk monosakarida telah dikaji menggunakan hidrolisis berasid. Kepekatan asid adalah antara faktor utama yang mempengaruhi penghasilan gula penurun. Kesan kepekatan asid sulfurik yang berbeza iatu 1, 3 dan 5\% (i/i) terhadap sampel SKT dan SKM telah direkodkan dalam Rajah 2.

Secara keseluruhannya, tiada perubahan kandungan gula penurun yang dilihat dalam sampel hidrolisat SKT dengan pra-rawatan beralkali dan SKM tanpa pra- rawatan beralkali. Manakala, penghasilan gula penurun selepas hidrolisis berasid bagi hidrolisat sampel SKT (tanpa pra-rawatan beralkali) dan SKM (dengan prarawatan beralkali) menunjukkan pola yang hampir sama. Kepekatan gula penurun didapati meningkat selari dengan peningkatan kepekatan asid sulfurik daripada $1 \%$ kepada 3\% dan berlaku penurunan kepekatan gula penurun apabila 5\% asid sulfurik digunakan. Kepekatan $1 \%$ asid sulfurik mempunyai jumlah $\mathrm{H}+$ yang tidak mencukupi untuk menghasilkan radikal bebas berbanding dengan kepekatan 3\% asid sulfurik menyebabkan gula penurun yang dihasilkan tidak sampai kepada tahap maksimum. Walau bagaimanapun, nilai jumlah kepekatan gula penurun menurun pada kepekatan 5\% asid sulfurik disebabkan penambahan asid dalam kepekatan yang terlalu tinggi yang memusnahkan struktur dalaman gula penurun dan menyebabkan gula penurun yang dihasilkan menjadi berkurang (Aryani et al. 2013). Di samping itu, Hu dan Ragauskas (2012) melaporkan bahawa penggunaan asid yang berkepekatan tinggi akan memusnahkan gula penurun dan menghasilkan produk perencat seperti 5-hidroksimetilfurfural (HMF), asid levulinik dan asid formik.

Berdasarkan data analisis varians pada aras keyakinan 95\% $(\mathrm{p}<0.05)$, didapati bahawa jumlah kepekatan gula penurun yang dihasilkan adalah paling tinggi dengan menggunakan kepekatan 3\% asid sulfurik, sebanyak 0.87 $\mathrm{mg} / \mathrm{mL}$ dalam hidrolisat sampel SKT tanpa pra-rawatan beralkali dan $1.02 \mathrm{mg} / \mathrm{mL}$ dalam hidrolisat sampel SKM dengan pra-rawatan beralkali. Selain tu, penggunaan kepekatan $1 \%$ asid sulfurik terhadap hidrolisat sampel SKT tanpa pra-rawatan alkali telah menghasilkan sebanyak $0.52 \mathrm{mg} / \mathrm{mL}$ nilai kepekatan gula penurun, yang berbeza secara signifikan $(\mathrm{p}<0.05)$ berbanding hidrolisat sampel SKT yang lain. Di samping itu, hidrolisat sampel SKM yang lain tidak berbeza secara signifikan dengan beza yang tidak melebihi daripada $0.3 \mathrm{mg} / \mathrm{mL}$ antara satu sama lain.

Manakala, hasil kajian terhadap hidrolisat sampel SKT menunjukkan kaedah hidrolisis berasid tanpa pra-rawatan beralkali adalah lebih berkesan untuk menghasilkan gula penurun yang lebih banyak berbanding dengan hidrolisis berasid dengan pra-rawatan beralkali. Terdapat perbezaan yang amat ketara (melebihi 3 kali ganda) pada kandungan gula penurun dalam hidrolisat sampel SKT tanpa pra-rawatan beralkali berbanding sampel SKT dengan pra-rawatan beralkali (penggunaaan kepekatan 3\% asid sulfurik). Kebarangkalian kehadiran sisa lignin selepas hidrolisis berasid telah memberi kesan negatif yang ketara terhadap sampel disebabkan penjarangan fizikal dan penjerapan selulosa yang tidak produktif(Chen et al. (2016). Hasil ini adalah bertentangan 
dengan kajian terhadap hidrolisat sampel SKM dengan penghasilan gula penurun adalah didapati lebih tinggi terhadap sampel hidrolisis berasid dengan pra-rawatan beralkali. Secara teorinya, penggunaan pra-rawatan beralkali sebelum hidrolisis berasid mampu menyumbang kepada penghasilan gula penurun yang lebih tinggi kerana kandungan selulosa dan lignin daripada serat sabut kelapa akan terdegradasi menjadi gula penurun dengan menggunakan asid sulfurik $\left(\mathrm{H}_{2} \mathrm{SO}_{4}\right)$ (Aryani et al. 2013).

Walau bagaimanapun, secara keseluruhan, penghasilan gula penurun daripada proses asid hidrolisis adalah sangat rendah dengan kadar penukaran gula penurun yang maksimum tidak melebihi $5 \%$ untuk semua sampel. Ini menjadikannya tidak sesuai untuk digunakan sebagai substrat semasa proses fermentasi. Kekurangan kadar penukaran gula penurun dalam kedua-dua sampel sabut kelapa mungkin disebabkan struktur dan komposisi selulosa yang kuat yang tidak dapat dicerna dengan baik secara kimia (Jungnikl et al. 2008). Akan tetapi, kajian Bukhari et al. (2017) menunjukkan kadar penukaran gula yang tinggi (96\%) boleh didapati daripada sisa kanji hampas sagu yang dihidrolisis dengan kepekatan $1 \%$ asid sulfurik namun, suhu yang tinggi $\left(125^{\circ} \mathrm{C}\right)$ dan masa hidrolisis yang lebih lama (90 minit) diperlukan.

\section{HIDROLISIS BERENZIM}

Hidrolisis berenzim menggunakan enzim Accellerase 1500 pada kepekatan yang berbeza $(1,5,10,15$ dan $20 \%, \mathrm{i} / \mathrm{i})$ telah dijalankan terhadap sampel SKT dan SKM. Rajah 3 menunjukkan kesan kepekatan enzim terhadap penghasilan gula penurun daripada sampel sabut kelapa tanpa pra-rawatan beralkali dan sabut kelapa yang dikenakan pra-rawatan beralkali.

Pola penghasilan gula penurun adalah berbeza untuk hidrolisat sampel SKT dan SKM dengan kepekatan gula penurun meningkat $(p<0.05)$ berkadar langsung dengan peningkatan kepekatan enzim Accellerase 1500 bagi hidrolisat sampel SKT. Keputusan menunjukkan bahawa pola kepekatan gula penurun meningkat $(\mathrm{p}<0.05)$ apabila kepekatan enzim bertambah dari 1 ke $10 \%$ untuk hidrolisat sampel SKT yang dikenakan pra-rawatan beralkali $(5.30 \mathrm{mg} / \mathrm{mL}$ kepada $11.09 \mathrm{mg} / \mathrm{mL})$ dan tanpa pra-rawatan beralkali $(1.61 \mathrm{mg} / \mathrm{mL}$ kepada $5.45 \mathrm{mg} / \mathrm{mL})$. Hasil ini selari dengan kajian oleh Soontornchaiboon et al. (2016), dengan kepekatan enzim yang tinggi tidak menyumbang kepada peningkatan kandungan gula penurun di dalam sampel sisa biojisim. Secara teorinya, pada kepekatan enzim yang rendah, bilangan molekul substrat melebihi bilangan molekul enzim. Oleh itu, cuma sebilangan kecil molekul substrat bertindak balas dengan molekul enzim. Apabila kepekatan enzim bertambah, lebih molekul substrat dapat bertindak balas dengan molekul enzim sehingga mencapai satu tahap maksimum (Robinson 2015).

Berdasarkan data analisis varians pada aras keyakinan $95 \%(\mathrm{p}<0.05)$, didapati kepekatan gula penurun paling tinggi adalah dalam hidrolisat sampel SKT dengan pra-rawatan beralkali menggunakan kepekatan 10\% enzim Accellerase 1500 (11.09 mg/mL). Manakala, kepekatan 1\% enzim Accellerase 1500 terhadap sampel SKT tanpa pra-rawatan beralkali adalah paling rendah $(1.61 \mathrm{mg} / \mathrm{mL})$. Selain itu, kandungan gula penurun bagi hidrolisat sampel SKT dengan pra-rawatan adalah lebih tinggi secara signifikan $(\mathrm{p}<0.05)$ berbanding sampel tanpa pra-rawatan dengan beza melebihi $2 \mathrm{mg} / \mathrm{mL}$ (penggunaan kepekatan 5\% enzim Accellerase 1500). Manakala, hidrolisat sampel SKT dengan pra-rawatan beralkali yang menggunakan kepekatan $1 \%$ dan juga $5 \%$ enzim Accellerase 1500 tidak mempunyai beza yang signifikan $(<1.5 \mathrm{mg} / \mathrm{mL})$ dengan hidrolisat sampel SKT tanpa prarawatan beralkali yang diproses menggunakan kepekatan 10\% enzim Accellerase 1500.

Manakala, keputusan hidrolisat sampel SKM menunjukkan pola penghasilan gula penurun meningkat dengan peningkatan kepekatan 1 kepada $5 \%$ enzim Accellerase 1500 untuk sampel SKM yang dikenakan pra-rawatan beralkali (5.53 kepada $15.00 \mathrm{mg} / \mathrm{mL}$ ) dan tanpa pra-rawatan beralkali (3.64 kepada $9.92 \mathrm{mg}$ / $\mathrm{mL})$. Sebaliknya, berlaku sedikit penurunan yang tidak signifikan $(\mathrm{p}<0.05)$ pada penghasilan gula penurun dalam hidrolisat sampel SKM apabila kepekatan 10\% enzim Accellerase 1500 digunakan, dengan nilai tersebut berkurang kepada $12.04 \mathrm{mg} / \mathrm{mL}$ bagi sampel dengan prarawatan beralkali dan $9.60 \mathrm{mg} / \mathrm{mL}$ untuk sampel tanpa pra-rawatan beralkali. Ini adalah kerana pada kepekatan $10 \%$ Accellerase 1500 , penurunan aktiviti enzim berlaku disebabkan semua bahagian aktif enzim telah dipenuhi dengan substrat untuk membentuk kompleks enzimsubstrat (Robinson 2015). Selain itu, menurut Jones dan Vasudevan (2010), penggunaan kepekatan enzim Acellerase 1500 yang tinggi menyebabkan penurunan hasil gula penurun kerana terdapat sebahagian enzim selulase tidak aktif untuk menjalankan fungsinya dalam membantu pemecahan selulosa kepada gula penurun.

Walau bagaimanapun, berdasarkan data analisis varians pada aras keyakinan 95\% $(\mathrm{p}<0.05)$, kepekatan gula penurun yang paling tinggi $(15.00 \mathrm{mg} / \mathrm{mL})$ dalam hidrolisat sampel SKM dengan pra-rawatan beralkali yang menggunakan kepekatan 5\% enzim Accellerase 1500 adalah tidak berbeza secara signifikan dengan hidrolisat sampel SKM dengan pra-rawatan beralkali yang menggunakan kepekatan $10 \%$ enzim Accellerase $1500(12.04 \mathrm{mg} / \mathrm{mL})$. Selain itu, dapat diperhatikan nilai 
kepekatan gula penurun yang rendah dan tidak signifikan antara hidrolisis berenzim bagi sampel SKM tanpa prarawatan beralkali $(3.64 \mathrm{mg} / \mathrm{mL})$ dan sampel SKM dengan pra-rawatan beralkali $(5.53 \mathrm{mg} / \mathrm{mL})$ menggunakan enzim Accellerase 1500 berkepekatan 1\%. Di samping itu, kedua-dua hidrolisat sampel SKM tanpa pra-rawatan beralkali menggunakan kepekatan 5\% dan 10\% mempunyai beza kepekatan yang tidak signifikan terhadap hidrolisat sampel SKM dengan pra-rawatan beralkali menggunakan kepekatan $1 \%(<5.0 \mathrm{mg} / \mathrm{mL})$ dan juga $10 \%(<2.5 \mathrm{mg} /$ $\mathrm{mL}$ ) enzim Accellerase 1500.

Secara keseluruhannya, kedua-dua hidrolisat SKT dan SKM menunjukkan jumlah kepekatan gula penurun yang terhasil pada semua kepekatan Accellerase 1500 (1, 5 dan $5 \%$, i/i) dengan pra-rawatan beralkali adalah lebih tinggi secara signifikan $(\mathrm{p}<0.05)$ berbanding dengan tanpa rawatan beralkali. Dalam konteks ini, pra-rawatan adalah kaedah yang penting untuk menyingkirkan lignin dan hemiselulosa daripada sabut kelapa serta meningkatkan kecekapan pencernaan selulosa. Pra-rawatan dengan menggunakan alkali menyebabkan kesan pembengkakan pada permukaan sabut kelapa yang disebabkan oleh pemecahan dan saponifikasi hemiselulosa. Jadi secara tidak langsung, kaedah ini mampu meningkatkan luas permukaan bahan lignoselulosa dan membolehkan proses hidrolisis berenzim berlaku pada tahap yang lebih maksimum dalam penukaran selulosa kepada gula penurun (Han et al. 2012). Menurut Kim dan Han (2012), sebanyak $78.7 \%$ gula penurun terhasil daripada jerami padi yang dikenakan pra-rawatan alkali yang menunjukkan kadar hidrolisis dan percernaan selulosa yang tinggi berbanding tanpa rawatan yang hanya menghasilkan 20\% gula penurun.

Hasil kajian daripada hidrolisis berenzim menunjukkan kadar penukaran maksimum gula penurun yang agak tinggi, sebanyak 55\% selulosa telah dicerna kepada monosakarida (gula penurun) dalam hidrolisat sampel SKT dan $60 \%$ dalam hidrolisat sampel SKM. Nilai kepekatan gula penurun yang tinggi telah membuktikan bahawa hidrolisis berenzim mampu mencerna struktur selulosa sabut kelapa yang kuat berbanding hidrolisis berasid. Seterusnya, hidrolisat sampel SKT dengan prarawatan beralkali yang diproses menggunakan kepekatan $10 \%$ enzim Accellerase 1500 ( $11.09 \mathrm{mg} / \mathrm{mL}$ gula penurun) dan juga hidrolisat sampel SKM dengan pra-rawatan beralkali yang menggunakan kepekatan 5\% enzim Accellerase 1500 (12.04 mg/mL gula penurun) telah dipilih sebagai substrat dalam proses fermentasi.

\section{PENGHASILAN ASID LAKTIK D MELALUI PROSES FERMENTASI}

Proses fermentasi secara mod batch telah dijalankan di dalam $250 \mathrm{~mL}$ kelalang kon selama 48 jam untuk mengkaji penghasilan asid laktik D menggunakan kaldu hidrolisat yang dihasilkan daripada proses pra-rawatan beralkali dan juga hidrolisis berenzim. Proses fermentasi dijalankan menggunakan L. coryniformis subsp. torquens yang merupakan bakteria homofermentasi penghasilan asid laktik D. Rajah 4 menunjukkan profil fermentasi untuk kedua-dua hidrolisat SKT dan SKM pada suhu $37{ }^{\circ} \mathrm{C}$ dengan kelajuan 150 rpm dan tanpa kawalan $\mathrm{pH}$.

Pemerhatian terhadap profil fermentasi kedua-dua hidrolisat menunjukkan kepekatan asid laktik D yang meningkat selari dengan penurunan kepekatan gula penurun dalam kaldu hidrolisat SKT dan SKM sepanjang 48 jam proses fermentasi. Situasi ini mencadangkan bahawa gula penurun yang didapati daripada proses degradasi lignoselulosa hidrolisat telah digunakan oleh bakteria asid laktik untuk menghasilkan asid laktik D. Data daripada hidrolisat SKT menunjukkan kepekatan gula penurun menurun dari $10.19 \mathrm{mg} / \mathrm{mL}$ kepada $4.91 \mathrm{mg} / \mathrm{mL}$ dalam 48 jam dan selain itu, kepekatan asid laktik meningkat kepada $4.93 \mathrm{mg} / \mathrm{mL}$ selepas 48 jam. Manakala, hasil kajian daripada hidrolisat SKM menunjukkan penghasilan asid laktik D yang meningkat sebanyak $3.98 \mathrm{mg} / \mathrm{mL}$ selepas 48 jam fermentasi. Pada masa yang sama, didapati kandungan gula penurun juga menurun daripada 10.36 $\mathrm{mg} / \mathrm{mL}$ kepada $4.33 \mathrm{mg} / \mathrm{mL}$ sepanjang proses fermentasi. Secara keseluruhannya, hasil kajian menunjukkan kadar penukaran asid laktik D daripada gula penurun yang agak memuaskan semasa proses fermentasi oleh bakteria $L$. coryniformis subsp. torquen walaupun $\mathrm{pH}$ tidak dikawal semasa proses fermentasi. Nilai penukaran tersebut adalah $48 \%$ dalam kaldu hidrolisat SKT dan 38\% dalam kaldu hidrolisat SKM. Di samping itu, kadar penghasilan asid laktik D bagi kedua-dua kaldu hidrolisat SKT dan SKM adalah tidak melebihi $0.20 \mathrm{~g} / \mathrm{L} . \mathrm{j}$ yang agak perlahan jika dibandingkan dengan kadar penghasilan asid laktik (0.252 g/L.j) daripada proses fermentasi secara mod batch oleh Bacillus coagulans dalam kaldu sisa biojisim jagung (Garret et al. 2015). Hal ini kemungkinan disebabkan oleh bakteria L. coryniformis subsp. torquen tidak dapat menggunakan gula penurun sepenuhnya disebabkan keadaan kaldu yang berasid, dengan $\mathrm{pH}$ kaldu tidak dikawal dan menjadi faktor kepada penghasilan asid laktik D yang rendah. Pertumbuhan bakteria sudah terhenti pada $\mathrm{pH}$ 4.45. Berdasarkan kajian terdahulu ke atas sampel distillers dried grains with solubles (DDGS), sebanyak $24 \mathrm{mg} / \mathrm{mL}$ asid laktik D yang terhasil selepas 18 jam fermentasi dengan penggunaan glukosa sepenuhnya oleh bakteria L. coryniformis subsp. torquen dengan pengawalan kaldu pada pH 6 (Mohd Zaini et al. 2019). 


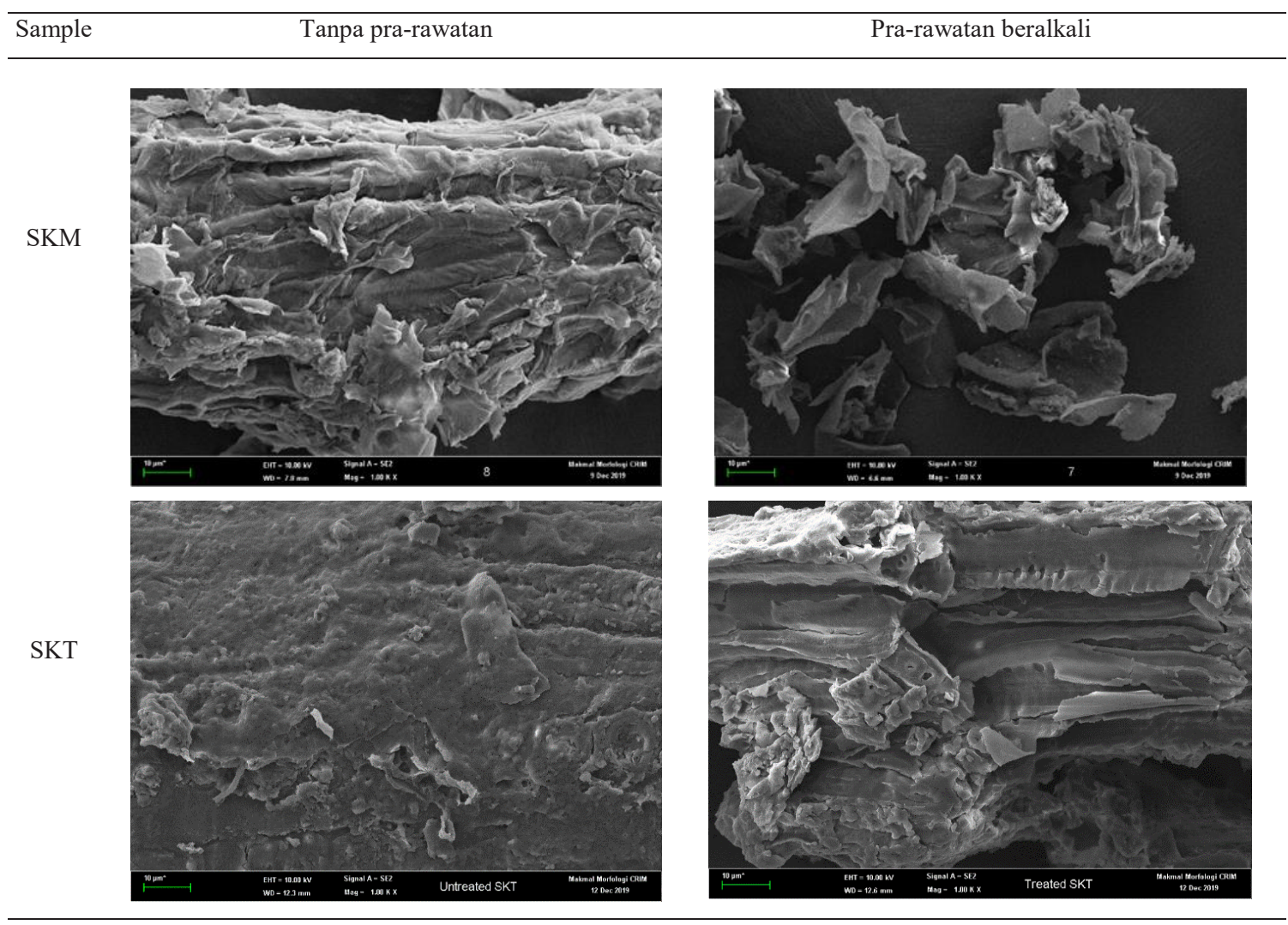

RAJAH 1. Ciri-ciri morfologi SKM dan SKT tanpa pra-rawatan dan yang dikenakan prarawatan beralkali $(\times 1000$ pembesaran $)$

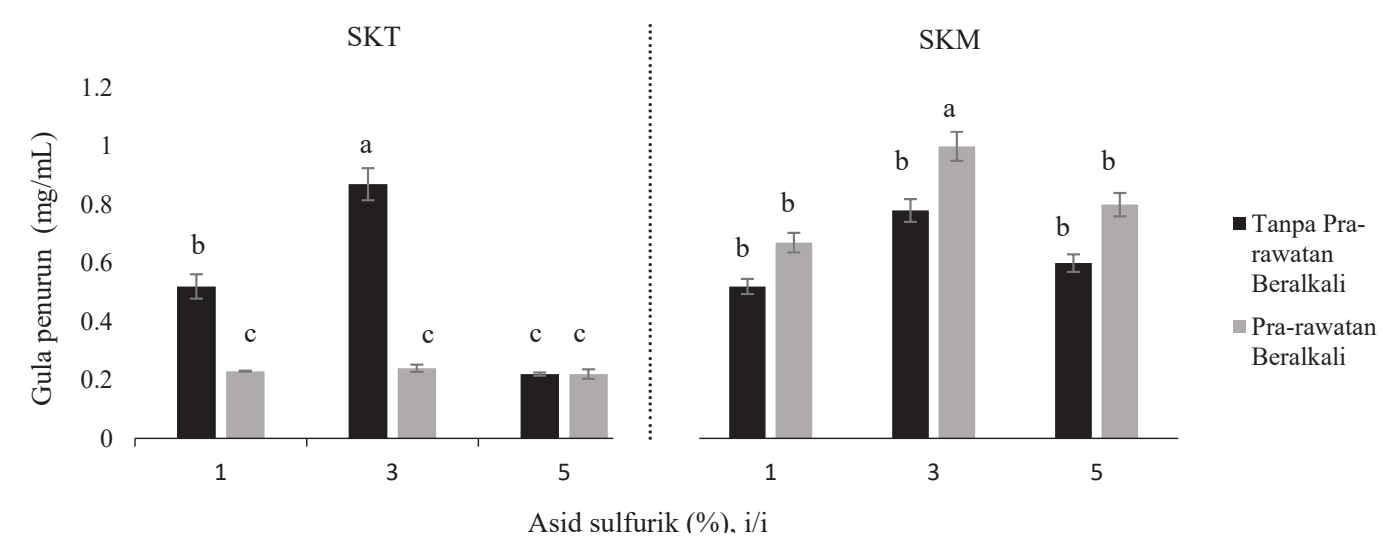

RAJAH 2. Pengaruh kepekatan asid yang berbeza terhadap jumlah kepekatan gula penurun yang dihasilkan melalui hidrolisis berasid pada suhu $121^{\circ} \mathrm{C}$ selama 30 minit. ${ }^{\text {a-c }}$ Graf bar dengan abjad yang berbeza menunjukan perbezaan yang signifikan $(\mathrm{p}<0.05)$ 


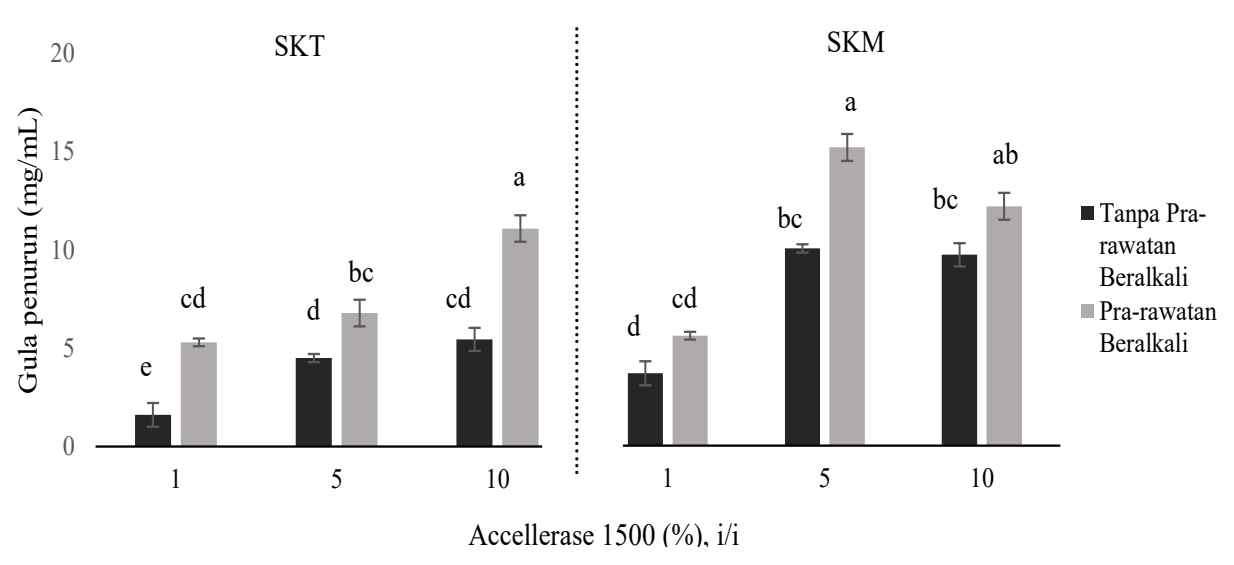

RAJAH 3. Pengaruh kepekatan enzim yang berbeza terhadap jumlah kepekatan gula penurun yang dihasilkan melalui hidrolisis berenzim pada suhu $50^{\circ} \mathrm{C}$ selama 24 jam. ${ }^{\text {a-e }}$ Graf bar dengan abjad yang berbeza menunjukan perbezaan yang signifikan $(\mathrm{p}<0.05)$
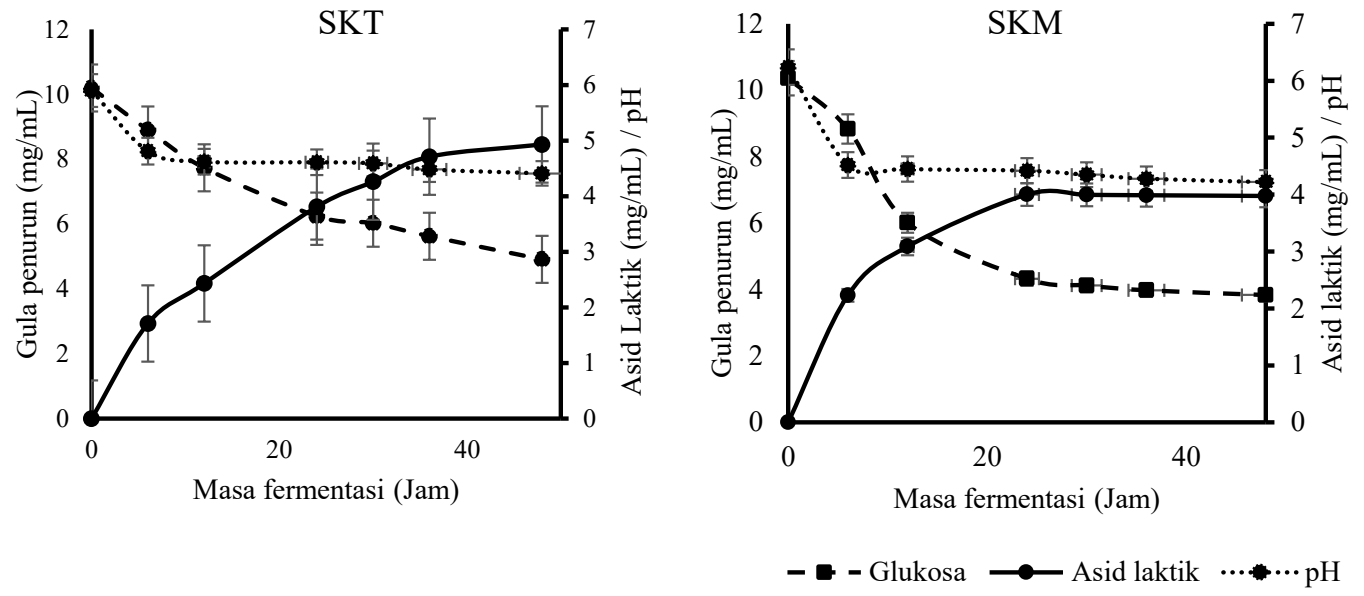

RAJAH 4. Kepekatan gula penurun dan asid laktik semasa proses fermentasi asid laktik D selama 48 jam pada $37^{\circ} \mathrm{C}$

\section{KESIMPULAN}

Hidrolisis berenzim merupakan kaedah yang lebih berkesan untuk menghasilkan gula penurun yang optimum dengan kadar penukaran gula penurun yang maksimum sebanyak 55\% dalam hidrolisat SKM dan $60 \%$ dalam hidrolisat SKT berbanding dengan hidrolisis berasid $(<5 \%)$ untuk kesemua hidrolisat. Kepekatan gula penurun yang paling tinggi dapat diperhatikan dalam hidrolisat sampel yang dikenakan pra-rawatan beralkali, SKT $(11.09 \mathrm{mg} / \mathrm{mL})$ dengan penggunaan kepekatan 10\% enzim Acellerase dan juga SKM $(15.00 \mathrm{mg} / \mathrm{mL})$ yang menggunakan kepekatan 5\% enzim Accellerase 1500. Sementara itu, proses fermentasi telah menunjukkan kadar penukaran gula yang memuaskan dengan nilai sebanyak 48\% dalam kaldu hidrolisat SKT dan 38\% dalam kaldu hidrolisat SKM walaupun proses fermentasi tidak 
dikawal pH. Sebanyak $4.93 \mathrm{~g} / \mathrm{L}$ penghasilan asid laktik D direkodkan dalam kaldu hidrolisat SKT dan $3.98 \mathrm{~g} / \mathrm{L}$ asid laktik D terhasil dalam kaldu hidrolisat SKM selepas 48 jam proses fermentasi. Walaupun jumlah kepekatan asid laktik D adalah agak rendah tetapi, ia menunjukkan potensi biojisim SKT dan SKM sebagai kaldu dalam proses fermentasi untuk menghasilkan asid laktik D. Proses fermentasi menggunakan kaldu hidrolisat sabut kelapa dengan kawalan $\mathrm{pH}$ dicadangkan untuk penghasilan asid laktik D yang lebih baik pada masa akan datang.

\section{PENGHARGAAN}

Penyelidikan ini ditaja oleh geran GGPM-2018-066. Penulis ingin merakamkan setingi-tinggi penghargaan kepada Jabatan Sains Makanan, Fakulti Sains dan Teknologi, Universiti Kebangsaan Malaysia yang menyediakan kemudahan penyelidikan.

\section{RUJUKAN}

Abdel-Rahman, M.A., Tashiro, Y. \& Sonomoto, K. 2010. Lactic acid production from lignocellulose-derived sugars using lactic acid bacteria: Overview and limits. Journal of Biotechnology 156(4): 286-301.

Aryani, E., Kusumo, E. \& Supartono. 2013. Produksi bioetanol dari jerami padi (Oryza sativa L). Jurnal Institut Teknologi Nasional 2(2): 168-172.

Bensah, E.C. \& Mensah, M. 2013. Chemical pretreatment methods for the production of cellulosic ethanol: Technologies and innovations. International Journal of Chemical Engineering 2013: Article ID. 719607.

Borshchevskaya, L.N., Gordeeva, T.L., Kalinina, A.N. \& Sineokii, S.P. 2016. Spectrophotometric determination of lactic acid. Journal of Analytical Chemistry 71(8): 755-758.

Bukhari, N.A., Loh, S.K., Bakar, N.A. \& Ismail, M. 2017. Hydrolysis of residual starch from sago pith residue and its fermentation to bioethanol. Sains Malaysiana 46(8): 1269-1278.

Chen, H., Zhao, X. \& Liu, D. 2016. Relative significance of the negative impacts of hemicelluloses on enzymatic cellulose hydrolysis is dependent on lignin content: Evidence from substrate structural features and protein adsorption. ACS Sustainable Chemistry \& Engineering 4(12): 6668-6679.

Ciftci, D. \& Saldana, M.D.A. 2015. Hydrolysis of sweet blue lupin hull using subcritical water technology. Bioresource Technology 194: 75-82.

Dumbrepatil, A., Adsul, M., Chaudhari, S., Khire, J. \& Gokhale, D. 2008. Utilization of molasses sugar for lactic acid production by Lactobacillus delbrueckii subsp. delbrueckii mutant Uc-3 in batch fermentation. Appl. Environ. Microbiol. 74: 333-335.

Garrett, B.G., Srinivas, K. \& Ahring, B.K. 2015. Performance and stability of Amberlite ${ }^{\mathrm{TM}}$ IRA-67 ion exchange resin for product extraction and $\mathrm{pH}$ control during homolactic fermentation of corn stover sugars. Biochemical Engineering Journal 94: 1-8.
Garriga, M., Almaraz, M. \& Marchiaro, A. 2017. Determination of reducing sugars in extracts of Undaria pinnatifida (harvey) algae by UV-visible spectrophotometry (DNS method). Desarrollo E Innovación En Ingeniería 2007: 173-179.

Han, L., Feng, J., Zhang, S., Ma, Z., Wang, Y. \& Zhang, X. 2012. Alkali pretreated of wheat straw and its enzymatic hydrolysis. Brazilian Journal of Microbiology 43(1): 53-61.

Hu, F. \& Ragauskas, A. 2012. Pretreatment and lignocellulosic chemistry. Bioenergy Research 5(4): 1043-1066.

Jones, P.O. \& Vasudevan, P.T. 2010. Cellulose hydrolysis by immobilized Trichoderma reesei cellulase. Biotechnology Letters 32(1): 103-106.

Jungnikl, K., Paris, O., Fratzl, P. \& Burgert, I. 2008. The implication of chemical extraction treatments on the cell wall nanostructure of softwood. Cellulose 15(3): 407-418.

Kim, I. \& Han, J.I. 2012. Optimization of alkaline pretreatment conditions for enhancing glucose yield of rice straw by response surface methodology. Biomass and Bioenergy 46: 210-217.

Kucharska, K., Rybarczyk, P., Hołowacz, I., Łukajtis, R., Glinka, M. \& Kamiński, M. 2018. Pretreatment of lignocellulosic materials as substrates for fermentation processes. Molecules 23(11): 2937

Lin, Y. \& Tanaka, S. 2006. Ethanol fermentation from biomass resources: Current state and prospects. Applied Microbiology and Biotechnology 69(6): 627-642.

Lomelí-Ramírez, M.G., Anda, R.R., Satyanarayana, K.G., de Muniz, G.I.B. \& Iwakiri, S. 2018. Comparative study of the characteristics of green and brown coconut fibers for the development of green composites. BioResources 13(1): $1637-1660$

Mansuit, H., Samsuri, M.D.C., Sipaut, C.S., Yee, C.F., Yasir, S.M. \& Mansa, R. 2015. Effect of varying acid hydrolysis condition in Gracilaria sp. fermentation using sasad. In IOP Conference Series: Materials Science and Engineering 78(1): 012004.

Mohamed, R., Lim, M.T. \& Halis, R. 2013. Biodegrading ability and enzymatic activities of some white rot fungi on kenaf (Hibiscus cannabinus). Sains Malaysiana 42(10): 1365-1370.

Mohd Zaini, N.A., Chatzifragkou, A. \& Charalampopoulos, D. 2019. Microbial production of d-lactic acid from dried distiller's grains with solubles. Engineering in Life Sciences 19(1): 21-30

Ringkas, G. 2016. The effect of various pretreatment methods on empty fruit bunch for glucose production. Malaysian Journal of Analytical Sciences 20(6): 1474-1480.

Robinson, P.K. 2015. Enzymes: Principles and biotechnological applications. Essays in Biochemistry 59: 1-41.

Sommer, S.G., Hamelin, L., Olesen, J.E., Montes, F., Jia, W., Chen, Q. \& Triolo, J.M. 2016. Agricultural waste biomass. In Supply Chain Management for Sustainable Food Networks, edited by Iakovou, E., Bochtis, D., Vlachos, D. \& Aidonis, D. New York: John Wiley \& Sons, Ltd. pp. 67-106.

Soontornchaiboon Waesarat, Kim, S.M. \& Pawongrat, R. 2016. Effects of alkaline combined with ultrasonic pretreatment and enzymatic hydrolysis of agricultural wastes for high 
reducing sugar production. Sains Malaysiana 45(6): 955962.

Yang, X. 2006. Running LEO 1450VP SEM. Saint Mary's University.

Yew, B.S., Muhamad, M.A. \& Moha, S.B. 2019. Effect of alkaline treatment on structural characterisation, thermal degradation and water absorption ability of coir fibre polymer composites. Sains Malaysiana 48(3): 653-659.

Ysuhaimi. 2018. Kelapa: Analisis Industri. http://myagri.com my/2018/03/analisa-industri-kelapa/. Diakses pada $18 \mathrm{Mac}$ 2019.

Zaini, N.A.B.M., Chatzifragkou, A. \& Charalampopoulos, D. 2019. Alkaline fractionation and enzymatic saccharification of wheat dried distillers grains with solubles (DDGS). Food and Bioproducts Processing 118: 103-113.
Jabatan Sains Makanan

Fakulti Sains dan Teknologi

Universiti Kebangsaan Malaysia

46300 UKM Bangi, Selangor Darul Ehsan

Malaysia

*Pengarang untuk surat-menyurat; email: nurulaqilah@ukm. edu.my

Diserahkan: 4 Mac 2020

Diterima: 18 Ogos 2020 